\title{
P A R E C E R E S
}

\section{Investigação da Paternidade}

(Valor do diagnóstico pericial de "possibilidade")

\section{A. Almeida Júnior}

Quanto à confrontação fisionômica entre o autor e o réu, determinada pelo MM. Juiz e efetuada pelo perito, estou de inteiro acôrdo com êste último: é prova absolutamente destituída de valor, obsoleta, não servindo para mostrar, em grau científico, o vínculo de filiação entre um indivíduo e outro. Não foi diversa aliás, a afirmação que fiz e demonstrei em meu livro intitulado "Provas Genéticas da Filiação" (São Paulo, 1941).

Os demais exames realizados abrangeram cinco provas: 1) a dos grupos sanguíneos; 2) a dos tipos sanguíneos; 3) a do aglutinógeno $\mathrm{Rh}$; 4) a da sensibilidade gustativa para a feniltioureia, ou prova da P.T.C.; 5) a da conformação do lóbulo da orêlha. Tôdas essas provas -concluiu o perito - admitem a "possibilidade" do vínculo investigado.

Cabe-nos dizer, de início, que consideramos essa conclusão exata e bem fundamentada. Eossível, em face da Genética e dentro dos limites em que esta foi consultada no caso, que o Sr. J. G. C. seja o pai do investigante Sr. M. P., filho de dona A. E. P.. Resta averiguar, porém, o valor probatório de semelhante conclusão; isto é, indagar qual o pêso dela (se algum pêso ela tiver) para a decisão do pleito. Examinaremos o problema, primeiro, em tese. A seguir, vê-lo-emos em referência à caso concreto. 


\section{O problema em tese}

Qualquer das provas genéticas em uso (inclusive as sanguíneas) ora exclui o vínculo da paternidade, ora admite que êsse vínculo é possível.

Quando exclui, o seu valor é peremptório. é uma prova de certeza, não sendo defensável a atitude do juiz que: decida contra ela.

Por outro lado, entretanto, os resultados dos exames: genéticos (inclusive os do sangue) não têm nenhum valor probatório perante a Justiça, quando admitam que a paternidade é possivel. Porque, se dizem que é possível em relação a certo indivíduo, por ser êle portador de determinada fórmula genética, também o dizem em relação a todos os demais homens portadores de fórmula genética equivalente.

Há casos em que o resultado do exame não excluĩ nenhum homem: qualquer indivíduo do sexo masculino, colhido ao acaso, poderá ser o pai do investigante. Como atribuir, nesses casos, algum pêso a êsse exame, contra o Réu trazido ao tribunal, só porque êle, e não outro, foi o examinado?

Outros casos existem em que o resultado das verificações genéticas (uma só prova, ou o conjunto de várias provas) restringe o círculo dos possíveis pais: só, por exemplo, entre $30 \%$ ou $20 \%$ dos indivíduos do sexo masculino se poderá achar o pai do investigante, e entre êsses $30 \%$, ou $20 \%$, está o réu apontado. Mesmo assim a conclusão nada significa contra êste, pois não ináividualiza. E o que se tem em mira decidir é - "quem é o pai" - e não "quem pode ser o pai". Basta, pois, que a conclusão de "possibilidade" da perícia genética abranja dois homens, para que a Justiça se abstenha de decidir contra qualquer dêles, salvo prova individualizadora de outra natureza. 
Num pleito do Uruguai, a conclusão pericial, com base na Genética, mostrou que só em $12 \%$ dos homens se poderia achar o pai de determinada criança, estando o réu abrangido nesses 12\%. O juiz de 1a. instância levou semelhante conclusão em aprêço contra o réu: o Tribunal de Apelação, todavia, reformou a sentença, não vendo na aludida "presunção" nenhuma fôrça probatória (Lorenzo CARNELLI - "Los Caracteres grupales, el Derecho y la Ley". Montevidéo, 1940, págs. 116 e 117).

É por isso que nos Estados Unidos (onde tais casos dependem de um júri leigo) os autores aludem ao perigo de ordem psicológica, decorrente de juntar-se ao processo um resultado dêsse tipo: não vá o júri supor que a mera "possibilidade" deva influir contra o réu. As leis processuais estadunidenses contêm mesmo uma prudente restrição: os resultados só serão recebidos como prova se puderem estabelecer a "exclusão". Eis, por exemplo, o que preceitua o Código Civil da Califórnia (análogo, neste passo, ao de muitos outros Estados) :

"Sempre que se tornar conveniente para acusação ou a defesa, o Tribunal deverá determinar que as pessoas envolvidas no pleito sejam submetidas a uma ou mais provas sanguíneas. Os resultados serão recebidos como prova ùnicamente quando puderem estabelecer uma exclusão bem evidente" (n. 1.872).

Em suma, o resultado de "possibilidade", mesmo que restrito o número de indivíduos que colha em suas malhas, nunca pode ser alegado como prova contra o réu. Seu único efeito é o de deixar o campo livre à ação das outras provas. Pode-se até dizer: o resultado de "exclusão" coloca diante do acusado um escudo protetor inexpugnável; e o de "possibilidade" nega-lhe essa proteção, mas por si mesmo não o fere. 


\section{O problema concreto}

Tanto quanto o permitem os exames diretos praticados no caso em debate, pode-se dizer que o resultado de "possibilidade", a que chegou o ilustre perito, equivale, aqui, a uma prova ausente. Basta dizer que quatro dos cinco exames efetuados não levam a nenhuma restrição: por êles, qualquer homem, apontado ao acaso, pode ser o pai de M. P., filho de dona A. E. P.. E o exame que resta estabelece uma restrição pràticamente despresível. É o que passamos a demonstrar.

a) Prova dos grupos sanguíneos. - A mãe é do grupo A; o filho é do grupo A. Ora, quando mãe do grupo A produz filho do grupo A, qualquer homem tomado ao acaso pode ser o pai, seja êle do grupo $\mathrm{A}$, do grupo $\mathrm{B}$, no grupo $\mathrm{O}$ do grupo AB. Nenhuma, absolutamente nenhuma restrição, na medida das verificações diretas.

b) Prova aglutinógeno $R h$. - A mãe é Rh positivo; o filho é Rh positivo. Para que mãe $R$ h positivo possa produzir filho $\mathrm{Rh}$ positivo, também qualquer homem serve: tanto os de Rh positivo como os de Rh negativo. Nenhuma restrição, tampouco.

c) Prova da sensibilidade gustativa. - A mãe é sensível ao papel P.T.C.; o filho é insensível. Qualquer homem, igualmente sensível ou insensível ao papel P.T.C., pode, com mãe sensível ao referido reativo, gerar filho insensivel. Nenhuma restrição.

d) Conformação do lóbulo da orêlha. - A mãe possui lóbulo aderente; o filho possui lóbulo aderente. Qualquer homem, ainda, tenha êle lóbulo aderente ou lóbulo livre, pode, com mulher de lóbulo aderente, produzir filho de lóbulo aderente. Nenhuma restrição. (Esta prova, aliás, como o próprio perito adverte e eu desde 1941 divulguei em meu livro acima citado, não é muito segura). 
Mediante essas quatro provas, portanto, o primeiro homem que se encontre na rua, e que se submeta a exames iguais aos do réu, dará o mesmo resultado que êste; isto é, da "possibilidade" de ser o pai de M. P., filho de dona A. E. P..

e) Prova dos tipos sanguíneos. E que resta. A mãe é MN; o filho é N. Nesse caso há uma restrição, pois homens de tipo $M$ (cêrca de $30 \%$ dos indivíduos) não podem ser pais de filhos de tipo N. Quaisquer outros homens, isto é, os restantes $70 \%$, podem ser.

\section{Em resumo}

Isto pôsto, resumamos o problema concreto. No município de B., onde se teria dado, em fins de 1918, a concepção do autor, haveria, na época dessa concepção, cêrca de 6.000 homens em idade de procriar (V censo de 1920). Setenta por cento dêsses homens, ou 4.200 (não levemos em conta os visitantes) possuiam qualidades genéticas que, de acôrdo com o exame pericial, os colocariam, na presente lide, em absoluto pé de igualdade com o Sr. J. C. C.. Qualquer dêsses 4.200 homens (sem falar nos visitantes), se apresentado ao eminente perito, permitiria que S. Exa. formulasse o mesmo diagnóstico de "possibilidade", a que chegou.

Diagnóstico que, como julgamos haver demonstrado, não tem por si a mínima serventia probatória. 